\title{
The Geology and Economic Evaluations of the Liqhobong Kimberlites, Lesotho
}

\author{
Clarke, J. ${ }^{1}$, Sobie, P.A. ${ }^{2}$, Wilkes, T.A. ${ }^{3}$ and P. Zweistra ${ }^{4}$ \\ 1. Messina Diamond Corportion, Suite 2800, 2 First Canadian Place, Toronto, Canada M5X 1C8 \\ 2. MPH Consulting Limited, Suite 1800, 150 York Street, Toronto, Canada M5H 3S9 \\ 3. MPH Consulting Botswana (Pty) Limited, P.O. Box 40792, Gaborone, Botswana \\ 4. Mineral-Logic. 11 Corsair Crescent, Constantia, Cape Town, RSA 7800
}

MPH Consulting Limited and Messina Diamond Corporation first became aware of the Liqhobong Kimberlites, and the Liqhobong Co-operative's operations there at an SADC-EU sponsored forum on mining investment held in Lusaka, Zambia in December of 1994. At that conference, representatives from the Department of Mines and Geology were extremely forthcoming with information and arranged for a site visit. In particular, a Liqhobong overview prepared by Mr. S.A. Sakhele of the Dept. of Mines, contained tables showing potentially economic recoveries, and values/carat being obtained by the Liqhobong Co-operative over the period 1979-1993. Specifically, the Co-op had averaged 0.37cpht and \$US 50.62/ct., in mining some $90,422 t$ during that time, reportedly split relatively evenly between the two pipes. This work by the Co-op, much of it at deeper levels than De Beers' 1960-era evaluations, is directly responsible for generating the current (May, 1996) option agreement between them and MDC, which allows MDC to determine the viability of establishing a commercial mine.

Before the formation of the Co-operative, the Liqhobong kimberlites in the Highlands of Lesotho had been occupied and mined on an artisanal basis since at least the 1950's. The kimberlites were then "discovered" as part of the Lesotho-wide program of Colonel Jack Scott in the late 1950's, and subsequently evaluated by Scott's company Basutoland Diamonds Limited which had participation rights reserved for De Beers in return for funding, and which made use of geologists from Anglo-American Corporation. Liqhobong, Kao and Letseng-laterae were all being mined by local people at that time. Kao and Letseng were extensively over-run by thousands of small-scale local miners, while at Liqhobong, lesser attention was being given. Although Col. Scott's teams had documented the occurrence of 33 pipes and 140 fissures in Lesotho, of which 24 were diamondiferous, the above three operations became the focus of subsequent, larger scale, evaluations.

At Liqhobong, the Basutoland teams consisted of a geologist with two field assistants and 25 labourers, with kimberlitic material treated in small (4'6") rotary pans. Their standard approach was to systematically dig pits to $\sim 18^{\prime}$ depths, and as well this was supplemented by trenches across the better exposed Satellite Pipe. Grades reported in 1973 by Nixon on the Scott work range from 15-21 cpht in the weathered kimberlite of the Main Pipe to $63 \mathrm{cpht}$ in a gravel bed immediately above the kimberlite. Grades at the Satellite Pipe were reported at that time as $21 \mathrm{cpht}$ in the gravels and $33 \mathrm{cpht}$ in the yellowground.

A \$US 2.5m Phase I programme carried out by Liqhobong Mining Development Company (Pty) Limited (LMDC), wholly owned local subsidiary of MDC, on their evaluation licence covering the kimberlites, during July-December 1996 consisted of a levelled survey, geophysical surveying and $6,253 \mathrm{~m}$ of core drilling along with petrography, indicator mineral geochemistry and microdiamond analysis of core. Briefly, results are as follows:

The geophysical surveying resulted in the discovery of a new Blow (termed the Discovery 
Blow) approximately $300 \mathrm{~m}$ east of the Main Pipe, and, with subsequent drilling, confirmed that the Dyke is part of a larger $2.5 \mathrm{~km}$ Fissure System which consists of several en echelon dykes.

The drilling established that the Satellite Pipe had a larger surface areal extent than presently exposed at $\sim 1.6 \mathrm{ha}$, with the deepest hole ending in tuffisitic kimberlite breccia (TKB) at $122.5 \mathrm{~m}$. The Main Pipe margins were delineated to $150 \mathrm{~m}$ vertical, with the deepest hole ending in tuffisitic kimberlite (TK) at $650 \mathrm{~m}$. Areal extent of the Main Pipe was found to be $\sim 9.5$ ha with walls dominantly vertical, rather than tapering. On the hypabyssal intrusives a hole intersected the known Blow at $50 \mathrm{~m}$ vertical and found to be $5.5 \mathrm{~m}$ wide, with its surface extent from stripping estimated at $\sim 0.10$ ha. Dykes were successfully intersected between the known pipes and Blow, and were also found west of Satellite Pipe and $\sim 400 \mathrm{~m}$ east of Blow, giving a total known strike length to the Fissure System of over $2.5 \mathrm{~km}$. The Discovery Blow was found to be $\sim 0.2 \mathrm{ha}$ at surface, and similarly to the Blow, approximately $5 \mathrm{~m}$ across at $50 \mathrm{~m}$ vertical below surface.

All field indications are that the hypabyssal kimberlites represent precursers to the pipes. Petrography has confirmed core logging interpretations of three separate tuffisitic kimberlite breccias of diatreme facies, possibly close to the diatreme-hypabyssal interface, in the Satellite Pipe, along with a hypabyssal phase. The Main Pipe appears to consist of a single large intrusion with only textural variations between tuffisitic kimberlite breccias and crystal tuffisitic kimberlite, all of diatreme facies, to $650 \mathrm{~m}$ vertical. The blows and dykes are all hypabyssal intrusives. All of the Liqhobong kimberlites are indicated to be monticellite kimberlites of Group-1 variety.

Major element Kimberlitic Indicator Mineral (KIM) Chemistry on the Liqhobong intrusives, and generally suggest only low grade kimberlites as follows:

Main Pipe - diamonds of peridotitic and eclogitic origins indicated to be present by the garnets recovered, ilmenites suggest moderate diamond preservation potential.

Sat. Pipe - diamonds of peridotitic and eclogitic origins indicated to be present by the garnets and chromites recovered, and ilmentites suggest moderate diamond preservation potential.

Dyke - $\quad$ diamonds of peridotitic origin indicated to be present by the garnets, ilmenites suggest moderate-to-good diamond preservation potential.

Blow - diamonds of peridotitic origin indicated to be present by the garnets and chromites recovered, ilmenites suggest moderate-to-good diamond preservation potential.

Disc. Blow - diamonds of peridotitic origin indicated to be present by the garnets recovered, ilmenites suggest moderate diamond preservation potential.

Trace element studies on garnets and chromites (Nickel Thermometry) carried out by Dr. W. Griffin at CSIRO in Australia, indicated a typical Kaapvaal Craton geotherm and lithosphere for Liqhobong although trending towards a marginal signature. Grade prognostications of 70$100 \mathrm{cpht}$ for the Satellite Pipe, and 50-70 cpht for the Main Pipe were tempered by Dr. Griffin's noting that phlogopite-related metasomatism is present and should lower the grades to the bottom of the range given, but which are much higher than either the sampling by De Beers, or the major element KIM's suggest. 
Two labs were used for microdiamond recoveries summarized below, namely Lakefield Research in Ontario, the main facility, and Scientific Services, Capetown the umpire facility:

\begin{tabular}{|c|c|c|c|c|c|c|}
\hline Kimberlite & Weight(kg) & \#dia. & cts & $+1.0 \mathrm{~mm}$ & $+2.0 \mathrm{~mm}$ & $+1 \mathrm{~mm}$ grade \\
\hline Satellite Pipe & $2,160.90$ & 1850 & 4.200 & 156 & 13 & 139.07 \\
\hline Main Pipe & $4,163.00$ & 1335 & 2.788 & 96 & 13 & 49.61 \\
\hline Fissures & 46.80 & 14 & 0.028 & 2 & 0 & 37.18 \\
\hline Blow & 80.60 & 140 & 0.332 & 2 & 1 & 340.05 \\
\hline Discovery Blow & 263.60 & 328 & 0.296 & 9 & 0 & 55.16 \\
\hline
\end{tabular}

Analysis of these microdiamond abundances with respect to expected commercial recoveries, as well as all results to date, allowed MPH to recommend a Phase II bulksampling programme. Following independent corroboration by MDC, a \$US5.5M Phase II bulk-sampling commenced in February 1997, with camp and access up-grades as well as the fabrication of a 15tph DMS plant. The programme was designed to take the project into feasibility by providing a precise valuation of a large parcel of Liqhobong stones to accompany the grades produced by the sampling to give an initial value/ct and value/tonne for the kimberlites. The programme was laid out as follows, is independently monitored by Flour Daniel Southern Africa, and began in June:

Main Pipe - $\sim 40,000 \mathrm{~T}$ extracted from a 350m trench, sampling the pipe from margin to margin. Assuming a grade of $25 \mathrm{cpht}$, this sample would yield 10,000 carats.

Sat. Pipe - $\quad$ 7,500T extracted from surface trenching to yield 5,625 carats assuming a grade of $75 \mathrm{cpht}$.

Blow - $\quad \sim 1,000 \mathrm{~T}$ extracted from surface, yielding $\sim 1,000$ carats at $100 \mathrm{cpht}$.

Disc. Blow - 1,000T extracted from surface, yielding $\sim 250$ carats at $25 \mathrm{cpht}$.

Dyke - $\quad \sim 500 \mathrm{~T}$ extracted from surface, yielding $\sim 100$ carats at $20 \mathrm{cpht}$.

MDC has reported (20/01/98) that pre-feasibility studies of results to year-end have been positive (based on $\sim 30 \%$ of Main Pipe, and the total Satellite sample), and that "an economic diamond mine can be constructed at Liqhobong for approximately US $\$ 52$ million over an 18 month period. The study recommends that the open pit mine operates at 7,200 tonnes/day (2.6M tonnes/year), initially blending ore from the Main and Satellite Pipes. After six years the mine would expanded to treat 12,000 tonnes/day (4.4M tonnes/year) of Main Pipe kimberlite only, at an estimated capital cost of US $\$ 20$ million. Diamond production would be approximately $700,000 \mathrm{ct}$ annually during the project life of approximately 11.5 years. Fluor's estimate of project operating costs of US $\$ 4.43$ per tonne indicates that Liqhobong could be one of the lowest cost operators worldwide and could provide an operating margin of approximately $67 \%$."

The press release further states that, "Messina plans to continue the Main Pipe sampling and complete a bankable feasibility study during 1998", which bodes well for the establishment of the $2^{\text {nd }}$ commercial diamond mine, after Letseng-la-terae, in Lesotho. 